DE DE GRUYTER

OPEN
Journal of Intercultural Management

Vol. 7, No. 1, January 2015, pp. 23-41

DOI 10.1515/joim-2015-0002

\author{
Yoon Huat Chong ${ }^{*}$ \\ Institute of Value Management, Warsaw School of Economics, Poland
}

\author{
Halina Grzymała-Moszczyńska* \\ Jagiellonian University, Poland
}

\title{
The Chinese-perspective of Intercultural Competence Models Revisited
}

\begin{abstract}
Most intercultural competence models have been developed by Western experts based on Western theory and Western cultural values, and they are not culturally specific models. The lack of non-Chinese researchers to study and contribute to the construction of intercultural competence from a Chinese-perspective is a serious shortcoming, and most of the models developed by Chinese scholars are a replica of the Western models. A Chinese-perspective of intercultural competence model is indeed needed to reinterpret concepts and theories that are coined in the West, which are then widely used and generalized without any concrete-solid bases of their universality.

This paper deployed empirical study methods to analyze the content of the literature to understand the construct of Chinese-perspective intercultural competence models. Eight Chinese-perspectives of intercultural competence models formulated by Chinese scholars between 1998 and 2013 have been identified, two of them are researched in English, while six others are in Chinese. As a result, there are no significant differences in the components of those eight models, as most Chinese scholars agree that cognitive ability, emotional management and communication skills are three of the major components which constitute the Chinese version of intercultural competence models. This research is timely, and is worth conducting, due to increased Chinese investments throughout the world, and the power and influence of China as the world's largest economy. The results could be used as a guiding operational scheme to prepare business
\end{abstract}

\footnotetext{
*_darren@connectasia.pl; halina.grzymala-moszczynska@uj.edu.pl
} 
partners from both sides for successful cooperation.

However, one should recommend, in future research, that there be a comparison of Chinese-perspective models with Western-perspective models in order to delve deeper into the construct of the models to examine the degree to which the Chinese and Western-perspective of intercultural competence are complementary and compatible with each other.

Key words: intercultural competence, , intercultural competence model, Chinese, Chinese-perspective

\subsection{Background}

The definitions and constructions of intercultural competence should be defined and researched with the contribution of the scholars and experts from various cultures, backgrounds and fields. However, until now, the research paradigms and orientation of intercultural competence are mainly culturally specific based on the concepts of Western culture [Xu, 2011]. Xu [2011] claims, the lack of nonWestern researchers to study and contribute to the construction of intercultural competence from the non-Western perspective is faced with a serious problem; the construction of the exisiting intercultural competence model is obviously Westerncentric, mainly because of the establishment of Western communication theories, and Western cultural values as the bases of ideal communication.

Some researchers have included East-Asian perspectives in intercultural competence studies, but the inclusion is merely an additional component, which does not influence the construction of components themselves [Xu, 2011]. However, Luo [2013] reckons the differences between Western and non-Western perspectives of intercultural competence should perhaps complement each other and be examined for mutual compatibility.

Since China has just overtaken the USA as the world's largest economy, worth \$17.6 trillion, compared to America's \$17.4 trillion at the end of year 201**, establishment of the Chinese-perspective on intercultural competence models is essential to support academics and expatriates in becoming more aware, sensitive and competent in their contacts with people from different cultures. Expatriates who are interculturally competent are indeed needed to ensure the success of international cooperation, and to minimize the risks present in international business [Xiao \& Zhang, 2012].

** Duncan, Huge \& Martosko, David (2014). America usurped: China becomes world's largest economy - putting USA in second place for the first time in 142 years, 9 October 2014. From: http://www.dailymail.co.uk/news/article-2785905/ China-overtakes-U-S-world-s-largest-economy-IMF-says-economy-worth-176trillion-America-falls-second-place-time-1872.html 


\subsection{Problem statement, objective of the study and research method}

The term, intercultural competence is not easy to define as there are different definitions presented in the literature. Although this term has been used since the 1970s and 1980s with various concepts and models [Spitzberg \& Changnon, 2009, p. 9], most of them are understood as culturally universal but not culturally specific [Xu 2011]. In addition, many different terms are used as equivalents for 'intercultural competence' such as intercultural sensitivity, cultural competence, cross-cultural adjustment, multicultural competence, global competence [Deardorff, 2004, p. 23]. McClelland [1973] first mentioned the words 'competence and competencies' [Tian, Jin \& Xiong, 2013], although he does not define the words [Leonardo, 2008]. However, the words are referred to in terms of skills and personality variables needed in job performance, namely, communication skills, patience, moderate goal setting and ego development [McClelland, 1973]. It is essential to look at the Chinese-perspective of intercultural competence models and delve deeper into them in order to understand Chinese interpretations of intercultural competence.

Methodologically, the academic work of intercultural competence is a Westernbased approach, and the construction of intercultural competence models built by Chinese researchers mostly replicate the Western models [Xu, 2011]. Intercultural competence is not a popular topic for Chinese scholars and most of the research carried out by Chinese scholars on Chinese expatriates' intercultural competence is formed on the basis of Western theories, conducted mostly in 2013 and 2014 as shown in table 2.1 below.

Table 2.1: Research on intercultural competence of Chinese expatriates conducted based on Western theories

\begin{tabular}{l|l|l|l}
$\begin{array}{l}\text { Author } \\
\text { Guo \& Cai } \\
(2013)\end{array}$ & $\begin{array}{l}\text { The influence of } \\
\text { intercultural competence } \\
\text { on Chinese expatriates' job } \\
\text { satisfaction }\end{array}$ & Chinese & $\begin{array}{l}\text { Dimensions of intercultural } \\
\text { competence (Gertsen, 1992) }\end{array}$ \\
\hline $\begin{array}{l}\text { Tian, Jin \& Qi } \\
(2013)\end{array}$ & $\begin{array}{l}\text { On the intercultural } \\
\text { competence of Chinese } \\
\text { employees in MNCs- a } \\
\text { comparison between } \\
\text { Chinese firms going global } \\
\text { and foreign firms in China }\end{array}$ & Chinese & $\begin{array}{l}\text { Intercultural competence (Spencer } \\
\text { \& Spencer, 1933; Martin \& } \\
\text { Nakayama, 2004) }\end{array}$ \\
\hline $\begin{array}{l}\text { Liu } \\
(2013)\end{array}$ & $\begin{array}{l}\text { Research on the selection } \\
\text { of enterprise's expatriates } \\
\text { based on intercultural } \\
\text { competence theory }\end{array}$ & Chinese & $\begin{array}{l}\text { Intercultural competence (Gertsen } \\
\text { \& M.C, 1990) }\end{array}$ \\
\hline
\end{tabular}




\begin{tabular}{l|l|l|l}
\hline He \& Wang & $\begin{array}{l}\text { The influence of expatriate } \\
\text { management practices on } \\
\text { expatriates' cross-cultural } \\
\text { adjustment: evidence from } \\
\text { Chinese enterprises }\end{array}$ & Chinese & $\begin{array}{l}\text { Intercultural adaption (Black \& } \\
\text { Stephens, 1989) }\end{array}$ \\
\hline
\end{tabular}

In other respects, this paper brings valuable insights for the intercultural competence assessment tools, constructed on the basis of a Western-perspective, which is widely used to assess the intercultural competence level of students, business travelers, business leaders and expatriates.

Hence, this paper aims to analyze the content of the literature on Chineseperspective's intercultural competence models in order to understand the components and dimensions which constitute the models. Most of the literature analyzed is available in Chinese.

\subsection{Literature review}

It has been identified that eight intercultural competence models are Chinesefocused, seven of which are formulated by Chinese scholars, and one, Ting-Toomey and Kurogi's [1998] model, is a joint research by Ting from China and Kurogi from Japan. The intercultural competence model developed by Ting-Toomey and Kurogi [1998] is believed to be the first Chinese or Asian-perspective version of an intercultural competence model, which is widely used and discussed internationally most probably due to the fact it is published in English. Subsequently, six other models have been constructed in Chinese language between 2007 and 2012. Luo's [2013] Guanxi intercultural competence model is the latest research done by a Chinese scholar in 2013, in the English language. The summary of the eight mentioned models are shown in table 3.1 below, followed by a detailed description of each model.

Table 3.1: Summary of Intercultural competence models formulated by Chinese researchers

\begin{tabular}{l|l|l} 
Author & Intercultural competence model & Language \\
\hline $\begin{array}{l}\text { Ting-Toomey \& } \\
\text { Kurogi (1998) }\end{array}$ & Facework-based model of intercultural competence & English \\
\hline Gao \& Wu (2007) & Intercultural competence model of Chinese expatriates & Chinese \\
\hline Yang (2008) & Building intercultural competence model for company F & Chinese \\
\hline Li \& Tang (2010) & $\begin{array}{l}\text { Intercultural competence of expatriate: theory and modeling } \\
\text { review }\end{array}$ & Chinese \\
\hline Li (2010) & $\begin{array}{l}\text { Intercultural competence model and empirical research of } \\
\text { expatriates }\end{array}$ & Chinese \\
\hline Zhao (2010) & $\begin{array}{l}\text { A theoretical and empirical study of Chinese expatriates } \\
\text { competency model }\end{array}$ & Chinese \\
\hline
\end{tabular}




\begin{tabular}{l|l|l}
\hline $\begin{array}{l}\text { Xiao and Zhang } \\
(2012)\end{array}$ & $\begin{array}{l}\text { The components of intercultural competence in international } \\
\text { business }\end{array}$ & Chinese \\
\hline Luo (2013) & $\begin{array}{l}\text { Guanxi competence as intercultural competence in business } \\
\text { contexts - a Chinese perspective }\end{array}$ & English \\
\hline
\end{tabular}

3.1 Ting-Toomey and Kurogi's [1998] facework-based model of intercultural competence

Ting-Toomey and Kurogi [1998] have developed a facework-based model of intercultural competence based on the concept of face in intercultural conflicts. Leung \& Chan [2001, p. 1575] reckon face is "dignity, pride and respect" gained by an individual for his status and social achievements. Facework, according to TingToomey [2005], is a communication strategy adopted by an individual to protect his face and the other person's face in order to avoid conflict, and to ensure both parties' images, reputations and dignity are not damaged [Ting-Toomey, 2005].

The model created with an Asian perspective which empasizes four competences, for instance, interaction skills, knowledge, mindfulness and facework competence criteria as shown in figure 3.1. The four components are interconnected [Vallejo, 2012, p. 89], changes in a particular component will influence the outcome and performance of other components [Spitzberg \& Changnon, 2009, p. 12]. The model highlights distinct intercultural competencies with emphasis on specific cultural characteristics [Vallejo, 2012, p. 89].

The cognitive component highlights the essential knowledge in understanding the cultural differences between individualism and collectivism, power distance, the concept of face, and communication style. The mindfulness dimension represents the significance of being open-minded in an unfamiliar situation, owning multiple visions, and being creative, reflexive and empathetic. The skill component features interactive abilities in listening, oberserving, trust building, facework management and collaborative dialogue. Spitzberg \& Changnon [2009, p. 12] states that cognitive, emotion and skill components have resulted in the fourth component, facework competence criteria, to embrace the higher possibility of appropriate, effective, adaptive and satisfying results. 
Figure 3.1 Ting-Toomey and Kurogi's [1998] facework-based model of intercultural competence

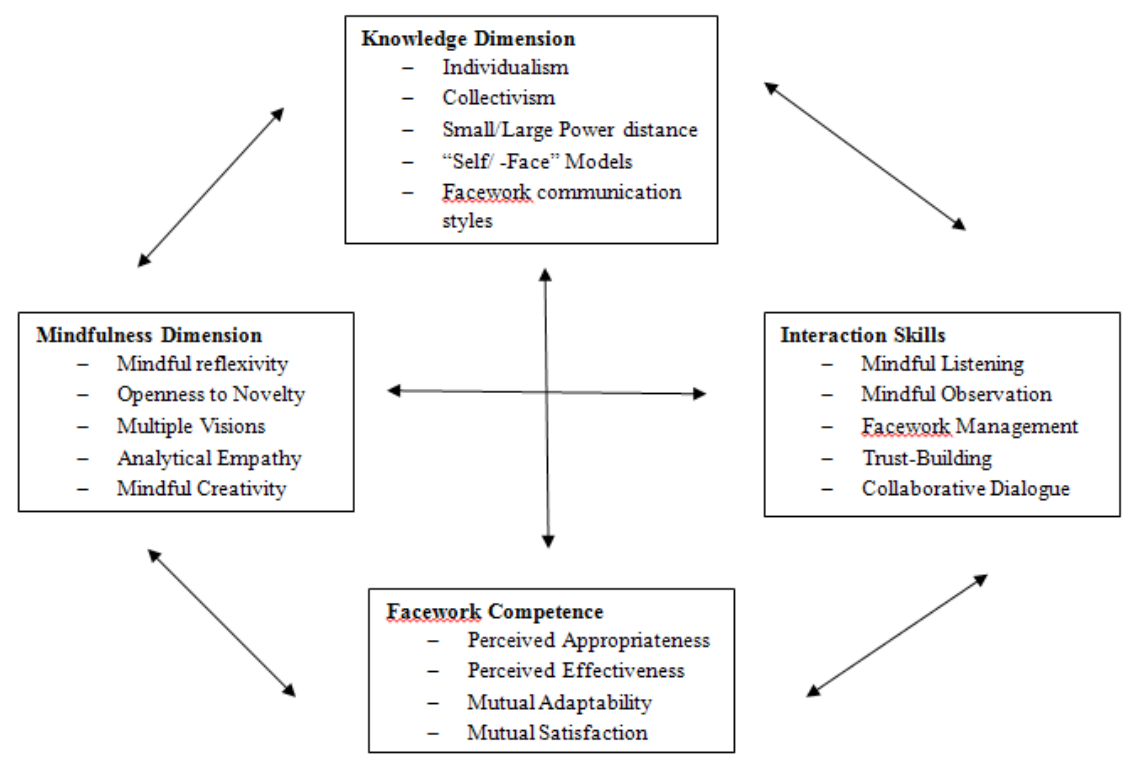

\subsection{Gao and Wu's [2007] intercultural competence model of Chinese expatriates}

The intercultural competence model is based on a survey conducted with three different categories of returned Chinese expatriates; specifically, human resource professors in a renowned university, cultural management and consulting experts, and middle and top level management personnel. The questionnaire was designed using the Delphi technique based on two selected intercultural competence measures, the Behavioural Assessment Scale for Intercultural Competence (BASIC) designed by Koester \& Olebe [1988) to monitor the communication behaviours, and Intercultural Sensitivity Scale (ISS) developed by Chen and Starosta's [2000] to measure intercultural sensitivity scale; and two interpersonal competence measures, Interpersonal Communication Inventory or ICI [Bienvenu, 1971] to examine the communication skills, and Social Problem-Solving Inventory-Revised or SPSI:R [D'Zurilla \& Nezu, 1990] to assess the ability of problem solving. Fifty completed questionnaires were received at the first stage and second stage of the survey, which took place respectively from November to December in 2014, and January to February in 2007.

At the conclusion of the study, researchers carried out in-depth interviews with eight selected senior managers to gather seventy-five attributes before narrowing 
them down to twenty-two attributes which comprised three components as shown in figure 3.2 below. Intercultural cognitive ability indicates the competence to recognize the intercultural issues with the cultural knowledge of the host country, which will make a positive impact on expatriate job performance. Emotional management capability covers the ability of expatriates to maintain positive attitudes towards an unfamiliar environment in a host country and confidence enhancement after attending emotional management training. The third component, interpersonal skills, derive from the cognitive and emotional management components, pertain to the enhancement of communication skills after acquiring cultural knowledge of the host country and confidence in cultural immersion. The interpersonal skills dimension can constitute the indicator needed to assess the effectiveness of intercultural training programs in a Chinese multinational company.

Figure 3.2 Gao and Wu's [2007] intercultural competence model of Chinese expatriates

\begin{tabular}{|c|c|}
\hline Component & Dimension \\
\hline \multirow{7}{*}{$\begin{array}{l}\text { Emotional } \\
\text { Ability }\end{array}$} & Initiative-driven \\
\hline & Able to restrain frustration \\
\hline & Able to endure psychological pressure \\
\hline & Has courage to take responsibility \\
\hline & Self-reflection and self-correction capability \\
\hline & Has strong sense of commitment \\
\hline & Has confidence to live and work in other cultures \\
\hline \multirow{8}{*}{ Cognitive ability } & Respects and comply with laws and regulations of host country \\
\hline & Participates in host country's cultural events, e.g. festivals \\
\hline & $\begin{array}{l}\text { Respects host country workplace etiquette and cultural management } \\
\text { ability }\end{array}$ \\
\hline & Respects the cultural values of colleagues in host country \\
\hline & Recognizes and interprets cultural differences \\
\hline & $\begin{array}{l}\text { Obtains political, economic, and cultural information of host } \\
\text { country }\end{array}$ \\
\hline & Practices "When in Rome, do as Romans do" \\
\hline & Able to observe \\
\hline \multirow{7}{*}{ Interpersonal skills } & Communicates effectively across cultures \\
\hline & Takes initiative to establish contact with local people \\
\hline & Maintains and deepens ties with local people \\
\hline & Able to perform teamwork with those of different cultures \\
\hline & Manages interpersonal relationships in a flexible way \\
\hline & Able to manage cultural conflicts \\
\hline & Enjoys social interaction \\
\hline
\end{tabular}




\subsection{Yang's [2008] intercultural competence model for company $F$}

The intercultural competence model has been created for company $F$ which operates in the metal industry and is present in thirty-two countries. A specific intercultural competence model is vital for company $\mathrm{F}$ due to the fact that clients and some of the employees are from different cultural backgrounds. Out of fiftyone employees in Company F, eight are expatriates from the United Kingdom, India and Australia.

Prior to the survey, five performance indicators, namely, job accomplishment, innovation, teamwork, contribution to organization and career development have been identified after consultation with the Human Resources Department. To weigh the importance of those five indicators, data was collected and analyzed based on employees' performance appraisals from the previous year, and face-toface interviews conducted with the supervisors of the employees. As of result, it showed that job accomplishment was the most important indicator according to $60 \%$ of employees surveyed, followed by teamwork ability, $20 \%$, contribution to organization, $10 \%$, innovation and career development, with $5 \%$ respectively. With this result, the performance of the employees is evaluated.

On the other hand, a questionnaire designed by Shanghai Jiatong University was used to gauge the level of employees' intercultural adaptation, specifically on their intercultural intelligence, emotional intelligence and self-monitoring capabilities. $93 \%$ of forty-two employees returned the questionnaires, but only forty questionnaires were completed.

The results gathered from the performance evaluations and questionnaires were then examined via Statistical Package for the Social Sciences (SPSS). Four components with fifteen dimensions have been discovered as per figure 3.3.

The first component formed is about one's inclination to immerse oneself into other groups and cultures, and the openness to try and learn new things. Emotional intelligence (EQ), as a second component, highlights the emotional dimension in controlling and understanding one's own emotions, and recognizing other's emotions. The third component emphasizes the cognitive ability of the employees or the ability to be aware and recognize cultural differences of people from different countries, and also those from different provinces in China. The last component underlines the ability to adjust one's own behavior in different cultural settings, especially when one communicates and works with someone from culturally and linguistically diverse backgrounds. 
Figure 3.3 Yang's [2008] intercultural competency model for company F

\begin{tabular}{|c|c|}
\hline Component & Dimension \\
\hline \multirow{4}{*}{$\begin{array}{l}\text { Cultural immersion } \\
\text { ability }\end{array}$} & Enjoys getting along with people from different cultural backgrounds \\
\hline & Empathic and able to change perspective \\
\hline & Willing to share one's knowledge with others \\
\hline & Open minded, likes to experience new things \\
\hline \multirow{4}{*}{$\begin{array}{l}\text { Emotional Intelligence } \\
\text { (EQ) }\end{array}$} & Accept people from different cultural backgrounds and values \\
\hline & Emotionally stable, able to control own emotions \\
\hline & Recognizes and understands own emotions \\
\hline & Recognizes emotional change in others and adopts flexible solution \\
\hline \multirow[t]{3}{*}{$\begin{array}{l}\text { Awareness of cultural } \\
\text { differences }\end{array}$} & $\begin{array}{l}\text { Recognizes cultural differences when in contact with people from other } \\
\text { cultures }\end{array}$ \\
\hline & $\begin{array}{l}\text { Recognizes cultural differences between China and the West, and the } \\
\text { other provinces in China }\end{array}$ \\
\hline & Respects faith, religion and customs of others \\
\hline \multirow[t]{4}{*}{ Ability to adjust } & Fluent in English language, both written and spoken \\
\hline & $\begin{array}{l}\text { Able to adjust own communication style, e.g. tones, intonation and } \\
\text { gestures }\end{array}$ \\
\hline & $\begin{array}{l}\text { Able to understand and judge the behaviour and communication style } \\
\text { of others }\end{array}$ \\
\hline & Has experience working in cross-cultural teams \\
\hline
\end{tabular}

\subsection{Li and Tang's [2010] intercultural competence theory and model of} Chinese expatriates

The intercultural competence model is developed based on the model of Gao \& Wu [2007] for employees of a power plant equipment manufacturer. The targeted company was aware of the importance of expatriate intercultural competence once the company doubled the operating income by winning twenty overseas projects in a short span of time between 2002-2007.

Eleven successful overseas project managers were selected to participate in the Behavioral Event Interview or BEI to delve deeper into the successful or challenging significant incidents, which took place in the last six to twelve month period during their overseas assignments. Behavioral Event Interview questions focus on exploring how respondents dealt with challenging situations in the past as their past behaviour could be one of the indicators of their future performance. The interview results were gathered to conduct subsequent interviews with nine Human Resource specialists in order to understand the performance of the project managers based on their behaviour, and to sort out the definition and the component of intercultural competence.

It was concluded that the cognitive, emotional and communicative components are the three main components for this model. The cognitive component highlights a few key words such as 'learning, experience, cultural knowledge, understanding, 
information gathering and internalization'; whereby, the emotional component refers to ability to handle emotions, that includes being able to manage stress, being flexible, possessing the drive to take initiative, being able to adapt, and being culturally and politically sensitive. As for the communication component, many managers emphasize that strong cultural knowledge and good communication skills in English are a solid base for business negotiations, coordination and cooperation. Worth mentioning, Li and Tang [2010] emphasize that proficiency in English is not enough, Chinese expatriates should also be able to communicate in the local language as it helps them to adapt and understand local culture.

Figure 3.4 Li and Tang's [2010] intercultural competence theory and model of Chinese expatriates

\begin{tabular}{l|l} 
Component & Dimension \\
\hline \multirow{2}{*}{ Cognitive ability } & Possess rich cultural knowledge \\
\cline { 2 - 2 } & Being understanding \\
\cline { 2 - 2 } & Feel sympathy towards others \\
\cline { 2 - 2 } & Being interculturally sensitive \\
\cline { 2 - 2 } Commun ability & Know how to manage emotion \\
\cline { 2 - 2 } & Have good communication skills \\
\cline { 2 - 2 } & Perform duties with appropriate behavior and character \\
\cline { 2 - 2 } & Show respect to others
\end{tabular}

\subsection{Li's [2010] intercultural competence model of Chinese expatriates}

The survey was carried out on 209 expatriates from Chinese multinational companies such as Huawei, BWI, Broad group, Zhong Liang group, Hisense group and Sany group. The questionnaire, uses a Likert scale, was designed based on three intercultural competence assessment tools, the Behavioural Assessment Scale for Intercultural Competence (BASIC), the Multicultural Awareness Knowledge and Skills Survey Questions (MAKSS) and the Intercultural Adjustment Potential Scale (ICAPS). The questionnaire, after consultation with Michael Morley of the University of Limerick and Kevin Orr of the University of Hull was distributed to twelve middle-top managers from Chinese multinational companies, possessing overseas work experience. The data collected was then analysed via Statistical Package for the Social Sciences (SPSS), which has concluded four essential components for a Chinese-perspective intercultural competence model, namely, personal traits, cognitive ability, intercultural communication and intercultural motivation.

The personal traits component features the behavioral characteristics such a being open-minded, responsible, confident, mentally healthy and physically and emotionally stable. The communication component is another personal trait which not only emphasizes proficiency in languages, but it enhances the skills needed 
to establish, maintain and deepen the relationship with the local residents, and to respect and adapt to local social norms.

Meanwhile, the cognitive ability urges one to respect and comply with laws and regulations of the host country, to understand cultural differences, to be able to solve problems within different cultural frameworks and to be aware of the latest developments of the host country in order to relay accurate insights back to corporate headquarters.

The motivation component focuses on how Chinese expatriates cope with the challenge of living in a foreign land, as well as having the competence to perform the critical business development role. Therefore understanding the cultural background of the local residents before having contact with them is vital.

Figure 3.5 Li's [2010] intercultural competence model of Chinese expatriates

\begin{tabular}{|c|c|}
\hline Component & Dimension \\
\hline \multirow{5}{*}{ Interpersonal skills } & Emotionally stable \\
\hline & Has self-confidence \\
\hline & Open-minded \\
\hline & Responsible \\
\hline & Physically and mentally healthy \\
\hline \multirow{10}{*}{ Cognitive ability } & Respects and complies with laws and regulations of host country \\
\hline & Able to adapt to the life in host country \\
\hline & Respects the host culture and workplace etiquette \\
\hline & Able to recognize and judge cultural differences \\
\hline & Able to communicate in local language \\
\hline & Able to integrate with different races and cultures and business entities \\
\hline & $\begin{array}{l}\text { Aware of host country's development and able to provide accurate } \\
\text { insights }\end{array}$ \\
\hline & Able to solve problems in different frameworks \\
\hline & Able to participate actively in cultural activities of the host country \\
\hline & Able to understand job roles of the management team in host country \\
\hline \multirow{6}{*}{ Communication skills } & Able to adapt to organizational culture of the host country \\
\hline & Able to adapt to local's social forms \\
\hline & Able to take the initiative to establish contact with local residents \\
\hline & Able to maintain and deepen ties with locals \\
\hline & Able to perform teamwork with others from different cultures \\
\hline & Able to get along with the local residents when outside of work \\
\hline \multirow{3}{*}{ Motivation to succeed } & Able to study the cultural background prior to contacting others \\
\hline & Enjoys living in an unfamiliar cultural environment \\
\hline & Confident of the business growth in the foreign subsidiary \\
\hline
\end{tabular}




\subsection{Zhao's [2010] intercultural competency model of Chinese expatriates}

Zhao [2010] employed an empirical study to finalize nine components of the intercultural competence for Chinese expatriates are based on the work of various scholars such as Ruben [1976], Mendenhall \& Oddou [1985], Koester \& Olebe [1988], Wiseman \& Hammer [1989], Earley \& Moakowski [2004], Earley \& Ang [2003], Tan [2004], Wang and Sun [2008], Fan [2009] and Gao \& Wu [2007]. Seventy-two dimensions obtained from content analysis were used to design a questionnaire, and data collected was then analyzed via Statistical Package for the Social Sciences (SPSS). As shown in figure 3.6, the nine components can be divided into three main elements, cognitive capabilities, emotional abilities and behavioral or social skills. The first three components are grouped into cognitive capabilities, which comprise cognitive ability, initiative (openness) and alignment with corporate culture. The desire for achievement, intercultural motivation and stress management ability constitute the emotional abilities of the ideal Chinese expatriate who has had contact with others from different cultures. The final element, behavioral or social skills are integrated by the three other components which emphasize the significance of communication skills, team work and project management skills. In conclusion, Zhao (2010) reckons empirical research has its limitation in formulating an intercultural competence model for Chinese expatriates as the content selection is too random, and therefore this method should be further tested and researched.

Figure 3.7 Zhao's [2010] intercultural competency model of Chinese expatriates

\begin{tabular}{|c|c|}
\hline Components & Dimension \\
\hline Initiative (openness) & $\begin{array}{l}\text { Open minded, curious about new things, accepts new ideas, courage to } \\
\text { try, and willing to share with others }\end{array}$ \\
\hline Need to achieve & $\begin{array}{l}\text { Strong desire to succeed, not content with the status quo, always sets } \\
\text { high goals for oneself, likes to complete challenging task, and demands } \\
\text { oneself to overcome obstacles }\end{array}$ \\
\hline Communication skills & Able to communicate clearly and give feedback openly \\
\hline Teamwork & Promotes team collaboration to achieve goals \\
\hline Motivation & $\begin{array}{l}\text { Takes action from intercultural motivation, self-confidence and } \\
\text { courage, adjusts to different cultures and interests }\end{array}$ \\
\hline Cognitive ability & $\begin{array}{l}\text { Aware and recognizes cultural differences and views culture from a } \\
\text { different perspective }\end{array}$ \\
\hline $\begin{array}{l}\text { Stress management } \\
\text { ability }\end{array}$ & $\begin{array}{l}\text { Copes under pressure with psychological endurance and self-adjustment } \\
\text { ability }\end{array}$ \\
\hline $\begin{array}{l}\text { Project management } \\
\text { Skills }\end{array}$ & $\begin{array}{l}\text { Responsible for the content of the project, to ensure the smooth } \\
\text { progress of the project execution }\end{array}$ \\
\hline $\begin{array}{l}\text { Corporate culture } \\
\text { compatibility }\end{array}$ & $\begin{array}{l}\text { Personal traits should be compatible with corporate culture, e.g. } \\
\text { concept of individualism, collectivism, etc. }\end{array}$ \\
\hline
\end{tabular}




\subsection{Xiao and Zhang's [2012] intercultural competence model in international business}

The Behavioural Event Interviews (BEI) were conducted with six senior managers, who were also pursuing their Executive Master of Business Administration (EMBA) studies in Wuhan, the capital city of Hubei province. They were chosen to join the interview due to their extensive overseas work experience. For this reason, the goal was to understand their cross-cultural experience and to compare their successes and failures during their overseas engagements. Subsequently, a Delphi technique was adopted to conduct a quantitative survey with sixty-one engineers and management leaders from two multinational automotive companies. The questionnaire which shortlisted seventy key dimensions of intercultural competence was then modified based on the feedback gained from the two hundred and fifty-six HR specialists. Finally, twenty-five finalized dimensions of intercultural competence have been identified and analyzed via Statistical Package for the Social Sciences (SPPS), as displayed in figure 3.7.

As a result, a four-component intercultural competence model was developed, with two second-level dimensions in each component, with a total of twenty third-level dimensions. The four mentioned dimensions are cognitive ability, communication skills, adaptation ability and ability to act. Xiao and Zhang [2012] concluded that local employees who are very competent with excellent work performance are not necessarily capable in cross-border business. In other respects, employees possessing superb personal qualities might not have high potential to work internationally. All in all, training, selection and intercultural competence assessment are interrelated.

Figure 3.7 Xiao and Zhang's [2012] intercultural competence model in international business

\begin{tabular}{|c|c|c|}
\hline Component & \begin{tabular}{|l|} 
Second-level \\
dimension
\end{tabular} & Third-level dimension \\
\hline \multirow{5}{*}{ Cognitive ability } & \multirow{2}{*}{ Culturally sensitive } & Have sharp observation skills \\
\hline & & Ability to perceive and recognize cultural differences \\
\hline & \multirow{3}{*}{ Cognitive desire } & Likes to experience different cultures \\
\hline & & Being empathetic and open-minded \\
\hline & & Understands different cultural values and norms \\
\hline \multirow{5}{*}{$\begin{array}{l}\text { Communication } \\
\text { skills }\end{array}$} & \multirow[t]{2}{*}{ Communication skills } & $\begin{array}{l}\text { Understands other languages and non-verbal } \\
\text { behaviors }\end{array}$ \\
\hline & & Has a flexible interpersonal style \\
\hline & \multirow{3}{*}{$\begin{array}{l}\text { Willingness to } \\
\text { communicate }\end{array}$} & Participates actively in various cultural activities \\
\hline & & Interacts actively with people from different cultures \\
\hline & & Keep contact with people from different cultures \\
\hline
\end{tabular}




\begin{tabular}{|l|l|l|}
\hline \multirow{5}{*}{$\begin{array}{l}\text { Adaptation } \\
\text { ability }\end{array}$} & Social adaptation & $\begin{array}{l}\text { Adapts to job demands and understands job scope } \\
\text { Adapts to different living environments and } \\
\text { necessities }\end{array}$ \\
\cline { 3 - 3 } & $\begin{array}{l}\text { Adapts to different ways of communicating and doing } \\
\text { things }\end{array}$ \\
\cline { 2 - 3 } & $\begin{array}{l}\text { Psychological } \\
\text { adaptation }\end{array}$ & $\begin{array}{l}\text { Healthy physically and mentally, and positive } \\
\text { emotionally }\end{array}$ \\
\cline { 3 - 3 } & Ability to withstand loneliness, stress and failure \\
\hline \multirow{4}{*}{ Ability to act } & Ability to execute & Ability to manage conflicts \\
\cline { 2 - 3 } & \begin{tabular}{l} 
Ability in team communication and collaboration \\
\cline { 2 - 3 }
\end{tabular} & Ability to act quickly \\
\hline & capability & Ability to analyze and judge \\
\cline { 3 - 3 } & Possesses professional knowledge and experience \\
\hline
\end{tabular}

\subsection{Luo's [2013] Guanxi competence as intercultural competence in business contexts}

Luo [2013] argues that most intercultural competence models are developed based on Western-perspectives and a non-Western perspective model is needed to look into possible synergies and correlations between these two perspectives. In reference to the work of Ting-Toomey and Kurogi [1998] on the facework-based model of intercultural competence, Luo is strongly convinced that guanxi is an important component in non-Western perspective or Chinese-perspective of an intercultural competence model in a business context. Guanxi is a Chinese word, it means the reciprocal exchange between two individuals to enhance their social and business relationships [Fan, 2002]. Guanxi is also a network of social relations between individuals, which is hierarchically structured [Hwang, 1987].

Luo [2013] applied three research methods to identify the constructs of Guanxibased intercultural competence model. The three methods consist of a focus group interview with ten Master of Business Administration (MBA) Chinese students from Wuhan University, subsequent literature reviews based on the work of Chinese scholars on guanxi, and a content analysis technique conducted via internet search engines such as Baidu, Google and Yisou.

Eventually, the results derived from the analysis have contributed to the formulation of a Guanxi-based model of intercultural competence with four key business-oriented components as seen in the following figure. The cultural component constitutes four dimensions in Chinese business culture, Guanxi, Mianzi or face, harmony and hierarchy, influences the other four components, as all components are interconnected. The economic component emphasizes the practices in business such as fairness, mutual benefit, business resources and profit. Whereby the individual component underlines the characteristics of personal attitudes, for instance, empathy, adaptation, commitment and reflexivity. The emotional level of the dimension is embedded in the social component. which contains favor exchange, bonding, trust and reciprocity. 
Luo's model is very culture-specific, it presents a cultural reference and a guide to work effectively with Chinese business counterparts, and to encourage other scholars to study and to explore intercultural competence from a culture-specific and non-Western perspective angle, in addition to the existing dominant Westernperspective intercultural competence models.

Figure 3.8 Luo's [2013] Guanxi competence as intercultural competence in business contexts

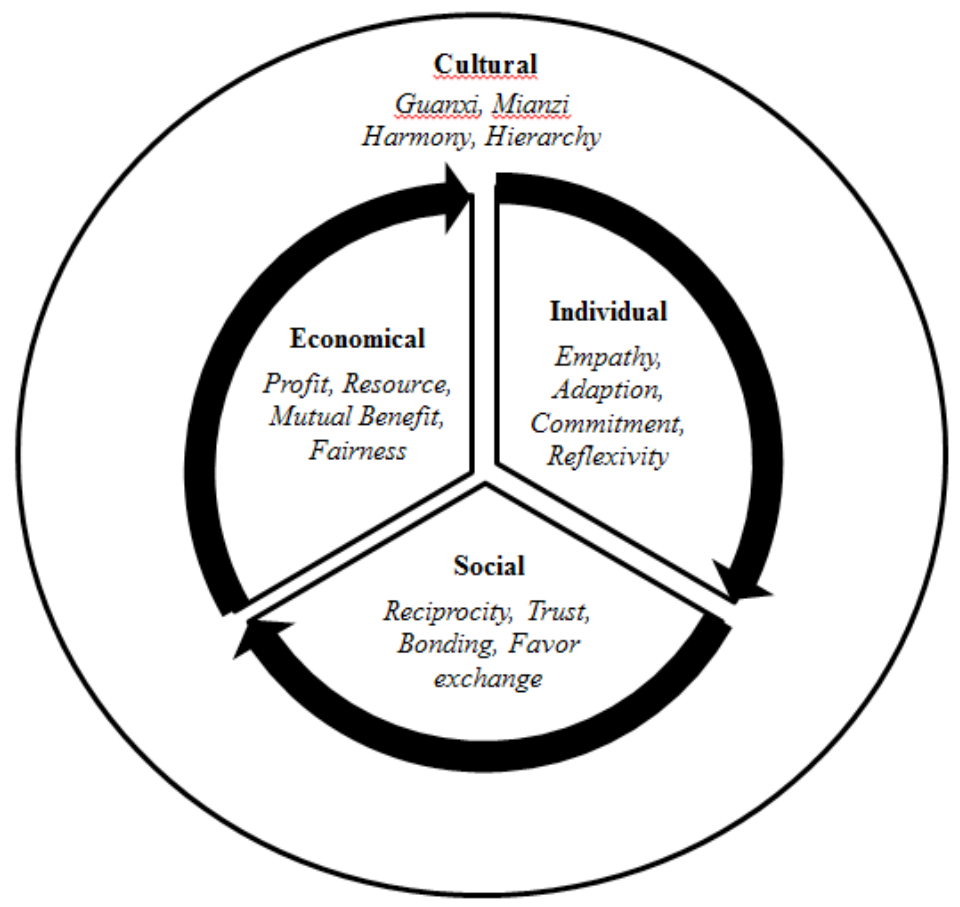

\subsection{Conclusion and future research}

Vallejo [2012], a non-Chinese scholar, has summarized all the intercultural competence models and its components by grouping them into three key components, which are cognitive capabilities, emotional abilities and behavioral or social skills. Based on Vallejo's [2012, p. 106-109] table, this paper has categorized the abovementioned eight Chinese-perspective models into the same format as shown below in figure 4.0. The figure shows clearly that all components can be identified and grouped into Vallejo's [2012] template, but the Chinese-perspective components and Vallejo's [2012] Western-perspective components are not necessarily the same. 
There are no significant differences in the constructions of those eight models. Most Chinese scholars agree that cognitive ability and communication skills are two of the major components, which constitute the Chinese version of intercultural competence models. They also emphasize that emotional abilities such as emotional management, motivation, stress management, high Emotional Intelligence and desire for achievement are essential for Chinese expatriates to live and work abroad. Since the objective of the paper is to analyze the Chinese-perspective of intercultural competence models, it is worth comparing these models with other models formulated with the Western-perspective in future research.

Figure 4.0 Summary of the components of Chinese-perspective intercultural competence

\begin{tabular}{|c|c|c|c|}
\hline Author & $\begin{array}{l}\text { Component } 1 \\
\text { (Cognitive capabilities) }\end{array}$ & $\begin{array}{l}\text { Component } 2 \\
\text { (Emotional abilities) }\end{array}$ & $\begin{array}{l}\text { Component } 3 \\
\text { (Behavioral/social } \\
\text { skills) }\end{array}$ \\
\hline \multirow{2}{*}{$\begin{array}{l}\text { Ting-Toomey } \\
(1998)\end{array}$} & \multirow[t]{2}{*}{ Knowledge dimension } & \multirow{2}{*}{$\begin{array}{l}\text { Mindfulness } \\
\text { dimension }\end{array}$} & \begin{tabular}{|l|} 
Interaction skills \\
\end{tabular} \\
\hline & & & $\begin{array}{l}\text { Facework competence } \\
\text { criteria }\end{array}$ \\
\hline $\begin{array}{l}\text { Gao \& Wu } \\
(2007)\end{array}$ & Cognitive ability & Emotional ability & Interpersonal skills \\
\hline \multirow[t]{2}{*}{$\begin{array}{l}\text { Yang } \\
(2008)\end{array}$} & $\begin{array}{l}\text { Cultural immersion } \\
\text { ability }\end{array}$ & \multirow[t]{2}{*}{$\begin{array}{l}\text { High Emotional } \\
\text { Intelligence (EQ) }\end{array}$} & \multirow[t]{2}{*}{ Ability to adjust } \\
\hline & $\begin{array}{l}\text { Awareness of cultural } \\
\text { differences }\end{array}$ & & \\
\hline $\begin{array}{l}\text { Li \& Tang } \\
(2010)\end{array}$ & Cognitive ability & Emotional ability & Communication skills \\
\hline \multirow{2}{*}{$\begin{array}{l}\mathrm{Li} \\
(2010)\end{array}$} & \multirow[t]{2}{*}{ Cognitive ability } & \multirow[t]{2}{*}{ Motivation to succeed } & Interpersonal skills \\
\hline & & & \begin{tabular}{|l|} 
Communication skills \\
\end{tabular} \\
\hline \multirow{3}{*}{$\begin{array}{l}\text { Zhao } \\
(2010)\end{array}$} & Cognitive ability & Motivation & Communication skills \\
\hline & Initiative (openness) & $\begin{array}{l}\text { Stress management } \\
\text { ability }\end{array}$ & Teamwork \\
\hline & $\begin{array}{l}\text { Corporate culture } \\
\text { compatibility }\end{array}$ & Need to achieve & Project management skill \\
\hline \multirow{2}{*}{$\begin{array}{l}\text { Xiao \& Zhang } \\
(2012)\end{array}$} & \multirow[t]{2}{*}{ Cognitive ability } & \multirow[t]{2}{*}{ Adaptation ability } & Communication skill \\
\hline & & & Ability to act \\
\hline \multirow[t]{2}{*}{$\begin{array}{l}\text { Luo } \\
(2013)\end{array}$} & Cultural knowledge & $\begin{array}{l}\text { Individual } \\
\text { characteristics }\end{array}$ & Social skills \\
\hline & & Economic practices & \\
\hline
\end{tabular}


Some of the Chinese-perspective models have been developed specifically for a particular Chinese company, such as the models of Yang [2008] for company F, and $\mathrm{Li}$ and Tang [2010] for a power plant equipment manufacturer, and other models are more universal, not dedicated to any specific industries.

To delve deeper, future studies can also look into the similarity or differences between the construction of intercultural competence models for the same industry players in different provinces in China, due to the fact that China, with over twenty provinces, has multiple ethnic groups who practice different cultural norms, with working professionals who possess different intercultural competencies.

Furthermore, it is obvious that although those described eight models are developed specifically for Chinese, they do adopt Western methodologies or with Western influence in their fieldworks, such as the employment of Western assessment tools, Behavioural Assessment Scale for Intercultural Competence (BASIC) by Gao and Wu [2007] and Li [2010], Behavioural Event Interview (BEI) technique used by Li and Tang [2010], and Xiao and Zhang [2012], as well as analysing results via Statistical Package for the Social Sciences (SPSS) by Li [2010], Zhao [2010], Xiao and Zhang [2012].

In short, six models developed by Gao and Wu [2007], Li [2010], Li and Tang [2010], Zhao [2010], Xiao and Zhang [2012] and Luo [2013] are etic models with some Western influences derived from outside a Chinese culture. On contrary, the models of Ting-Toomey \& Kurogi [1998] and Yang [2008] are emic models, which have concluded the intercultural competence of Chinese expatriates according to indigenous definitions.

The comparison between Western and non-Western perspective of intercultural competence model should use to explore the potential synergies between them without bringing any adverse implications and connotations [Luo, 2013]. A Chineseperspective of intercultural competence model is indeed needed to reinterpret concepts and theories that are coined in the West, which are then widely used and generalized without concrete-solid bases of their universality. Western-based intercultural competence models need to be scrutinized and analyzed thoroughly to confirm, to modify, or to deny altogether for their applications in different cultures. Unfortunately, the current practices in academia pay less attention to such an initial analysis.

The components identified in this paper do not represent the general picture of the intercultural competence model of the Chinese expatriates, as most of the respondents who took part in the research were mainly the 'returned expatriates'. Hence, it is highly recommended to conduct a consequent study which would involve Chinese expatriates who are currently living and working overseas and who might able to provide better insights and portrayals of the expatriate. 


\section{Bibliography}

Bienvenu, M. J. (1971). An interpersonal communication inventory. The Journal of Communication, 21, p. 381-388.

Chen, G.M., \& Starosta, W. J. (2000). The development and validation of the intercultural communication sensitivity scale. Human Communication, 3, p. 1-15.

Deardorff, D.K. (2004). The Identification and Assessment of Intercultural Competence. Department of adult and community college education, Graduate Faculty of North Carolina State University.

Duncan, Huge \& Martosko, David. (2014). America usurped: China becomes world's largest economy - putting USA in second place for the first time in 142 years, 9 October 2014. From: http:// www.dailymail.co.uk/news/article-2785905/China-overtakes-U-S-world-s-largest-economy-IMF-says-economy-worth-17-6trillion-America-falls-second-place-time-1872.html

D'Zurilla, T. J., \& Nezu, A. M. (1990). Development and preliminary evaluation of the Social ProblemSolving Inventory (SPSI). Psychological assessment: a journal of consulting and clinical psychology, 2, p. 156-163.

Evangelista, Leonardo. (2008). A Summary of McClelland, D. C. (1973). Testing for competence rather than for "intelligence". American Psychologist, 28, 1-14. From: http://www.orientamento.it/indice/a-summary-of-mcclelland-d-c-1973-testing-forcompetence-rather-than-for-intelligence-american-psychologist-28-1-14/

Fan, Ying. (2002). Questioning guanxi: Definition, classification and implications. International Business Review, 11, 543-561.

Fantini, Alvino \& Tirmizi, Aqeel. (2006). Exploring and Assessing Intercultural Competence. World Learning Publications. Paper 1.

From: http://digitalcollections.sit.edu/worldlearning_publications/1

Gao, Jiayong \& Wu, Dan. (2007). Zhōngguó wài pài rényuán kuà wénhuà shèngrèn lì zhǐbiāo tǐxì gòujiàn yánjiū. [Study on intercultural competence index of Chinese expatriates]. Science and Management, 2007, 28 (5): p. 169-173.

He, Yanzhen \& Wang, Yumei. (2014). The influence of expatriate management pratices on expatriates' cross-cultural adjustment: Evidence from Chinese enterprises]. Economic Management Journal (EMJ). Vol. 36, No. 4, issue no. 4, May 2014. p. 80-92.

Hwang, K. (1987). Face and favor. The Chinese power game. American Journal of Sociology, 92, p. 944-974.

Koester, J \& Olebe, M. (1988). The behavioral assessment scale for intercultural communication effectiveness. Journal of Intercultural Relations, Vol 12(3), 1988, p. 233-246.

Leung, T.K.P. \& Chan. R (2001). Face, favour and positioning-a Chinese power game. European Journal of Marketing 37, p. 1575-1598.

Li, Yan. (2010). Kuàguó qùyè wài pài rényuán kuà wénhuà shèngrèn lì móxing gòujiàn jí shį̌hèng yánjiü. [Intercultural competence model and empirical research of expatriates]. Hunan University. 
Li, Yijing \& Tang, Ningyu. (2010). Wài pài rényuán kuà wénbuà shèngrèn lì huígù yǔ móxíng gòijiàn. [Intercultural competence of expatriate: theory and modeling review]. Shanghai Jiao Tong University, Shanghai.

Luo, Xun. (2013). Guanxi competence as intercultural competence in business contexts - A Chinese perspective. Interculture Journal, H. 20. p. 69-89.

McClelland, D. C. (1973). Testing for competence rather than intelligence. American Psychologist, No.28(1), p. 1-14.

Spitzberg, B. H., \& Changnon, G. (209). Conceptualizing intercultural competence. In D. K. Deardorff (Ed.), The Sage handbook of intercultural competence (p. 2-52). Los Angeles, CA : Sage Publications, Inc.

Tian, Zhilong, Jin Shunrou-zi \& Xiong, Qi. (2013). Kuàguó gōngsī zhōngguó yuángōng de kuà wénhuà shèngrèn lì yánjiū -"zǒu chūqù" yǔ "zǒu jìnlái” qǔyè jiān de bĭjiào. [On the intercultural competence of Chinese employees in MNCs-A comparison between Chinese firms going global and foreign firms in China]. Journal of Zhejing Gongshang University, 2013, (5): 79-90.

Ting-Toomey, S. (2005). The matrix offace: an updatedface-negotiation theory, in Gudykunst,W.B.(Ed.), theorizing about intercultural communication. Sage, Thousand Oaks, CA, p. 71-92.

Ting-Toomey, S. \& Kurogi, A. (1998). Facework competence in intercultural conflict: an updated face-negotiation theory. International Journal of Intercultural Relations, Vol. 22, No. 2, p. 187-225.

Vallejo, J. L. (2012). Intercultural competence as a conducive factor of managers' readiness for organizational change. University of Strasbourg, France. p. 106-109.

Williams, R. (1983). Keywords: A vocabulary of culture and society. (2 $\left.{ }^{\text {nd }} \mathrm{ed}\right)$. London: Fontana Press.

Xu, Lisheng. (2011). Intercultural competence revisited. School of International Studies. Zhejiang University, Hangzhou.

Xiao, Fen \& Zhang, Jianmin. (2012). Guójì shāngwù z̧hōng de kuà wénhuà nénglì zhǐbiāo gòujiàn. [The components of ntercultural competence in international business]. Zhongnan University, Wuhan.

Yang, Xue. (2008). F gōngsi kuà wénhuà shèngrèn lì móxíng gòujiàn. [Building intercultural competence model for company F]. Antai College of Economics \& Management, Shanghai Jiaotong University.

Zhao, Lu. (2010). Zhōngguó wài pài rényuán shèngrèn tèshèng móxing lìlùn hé shį̌hèng yánjiū. [A theoritical and empirical study of Chinese expatriates competency model]. Beijing University of Posts and Telecommunications, Beijing. 